\title{
ALDEHYDES PARTICIPATION IN OXIDATIVE STRESS IN RAT THYMOCYTES IN VITRO
}

\author{
K. O. TOKARCHUK, O. V. ZAITSEVA \\ Palladin Institute of Biochemistry, National Academy of Sciences of Ukraine, Kyiv; \\ e-mail: kate_tokarchuk@ukr.net
}

A variety of lipid radicals are formed under oxidative stress development. The further oxidation of these radicals leads to formation of numerous aldehydes. They can form postsynthetic modifications in proteins and nucleic acids that disrupt their functions. In the present study aldehydes role in the formation of oxidative stress parameters in rat thymocytes was investigated. Two models were used: iron-stimulated oxidative stress and exogenous aldehydes exposure to thymocytes.

For oxidative stress induction, thymocytes $\left(2 \times 10^{6}\right.$ cells $/ \mathrm{ml} H B S S, p H$ 7.2) were exposed to different concentrations of $\mathrm{FeSO}_{4}(20,30,40 \mu \mathrm{M})$ and ascorbic acid $(100 \mu \mathrm{M})$ for $6 \mathrm{~h}$. It resulted in increase of levels of aldehydes 29 times $\left(90 \pm 6 \mathrm{nmol} / 10^{7}\right.$ cells $)$, these changes led to increase of TBARS levels 4.4 times; the levels of protein CO groups 10 times, cell mitochondrial activity and low-molecular weight SH groups were decreased 1.5 and 2.3 times, respectively. Treatment with aldehydes acceptor dimedone $(200 \mu M)$ significantly decreased the levels of aldehydes 3.7 times, TBARS 1.6 times and protein CO groups 5 times. It was shown that the levels of cell mitochondrial activity increase 1.4 times and the levels of SH groups 1.8 times.

To compare the effects of aldehydes in induction of oxidative stress, thymocytes $\left(2 \times 10^{6} \mathrm{cell} / \mathrm{sl} \mathrm{mBSS}\right.$, pH 7.2) were exposed to 50-600 $\mu M$ formaldehyde (FA), 50-600 $\mu \mathrm{M}$ glyoxal (GL), 50-600 $\mu M$ methylglyoxal (MGL), 1-15 $\mu$ M acrolein (ACR) for $6 \mathrm{~h}$. TBARS levels were increased for FA 1.3 times and for other aldehydes about 5-7 times. The levels of protein CO groups were increase for FA 3.7 times, for MGL 7 times, for GL 13 times, for ACR 22 times. Levels of SH groups were decreased for FA 1.5 times, for MGL 2.6 times, for GL 3 times, for ACR 9 times. A decrease of cell mitochondrial activity 1.5 times observe for all aldehydes. Obtained results prove the aldehydes participation in the formation of oxidative stress parameters and their capability to oxidative stress induction in the rat thymocytes.

Key words: oxidative stress, aldehydes, dimedone, thymocytes.

$\mathrm{E}$ ndogenous aldehydes are formed in the organism as by-products under lipid peroxidation (POL) or non-enzymatic glycosylation of proteins. POL, a complex process that occurs in all cellular membranes and involves the interaction of oxygen-derived free radicals with polyunsaturated fatty acids, finally results in a variety of reactive aldehydes. Glycation is a complex series of parallel and sequential reactions, in which reducing free carbonyl groups of carbohydrates react with the nucleophilic amino groups of biomolecules, producing a large number of various aldehydes. Reactive aldehydes formed during these ways are, for example, saturated aldehydes (ethanal [1], propanal), non-saturated ones (acrolein (ACR) [2], 4-hydroxynonenal [3]) and dicarbonyls (glyoxal (GL), methylglyoxal (MGL) [4]). Formaldehyde (FA) is an intermediate product of amino acid catabolism.
Aldehydes can alkylate amino groups of amino acids and basics of nucleic acids; react with proteins and peptides with further creation of stable intermediate products such as Schiff bases or N-hydroxymethyl adducts. In addition, these carbonyl compounds are able to form methylene bridges between close parts in proteins, that causes defection in their activity $[5,6]$.

Due to formation of end products of glycosylation and POL, aldehydes participate in pathogenesis of diseases related to oxidative stress, such as diabetic nephropathy, Parkinson's, Alzheimer's and other diseases that Fig. 1 illustrated. [7, 8, 28].

Liesivuori and Savolainen illustrated that aldehydes addition in vitro leads to the increase of reactive oxygen species (ROS) and POL products, and decrease of the level of glutathion [9]. For example, the most reactive among non-saturated aldehydes 
MONOSACCHARIDE STRESS

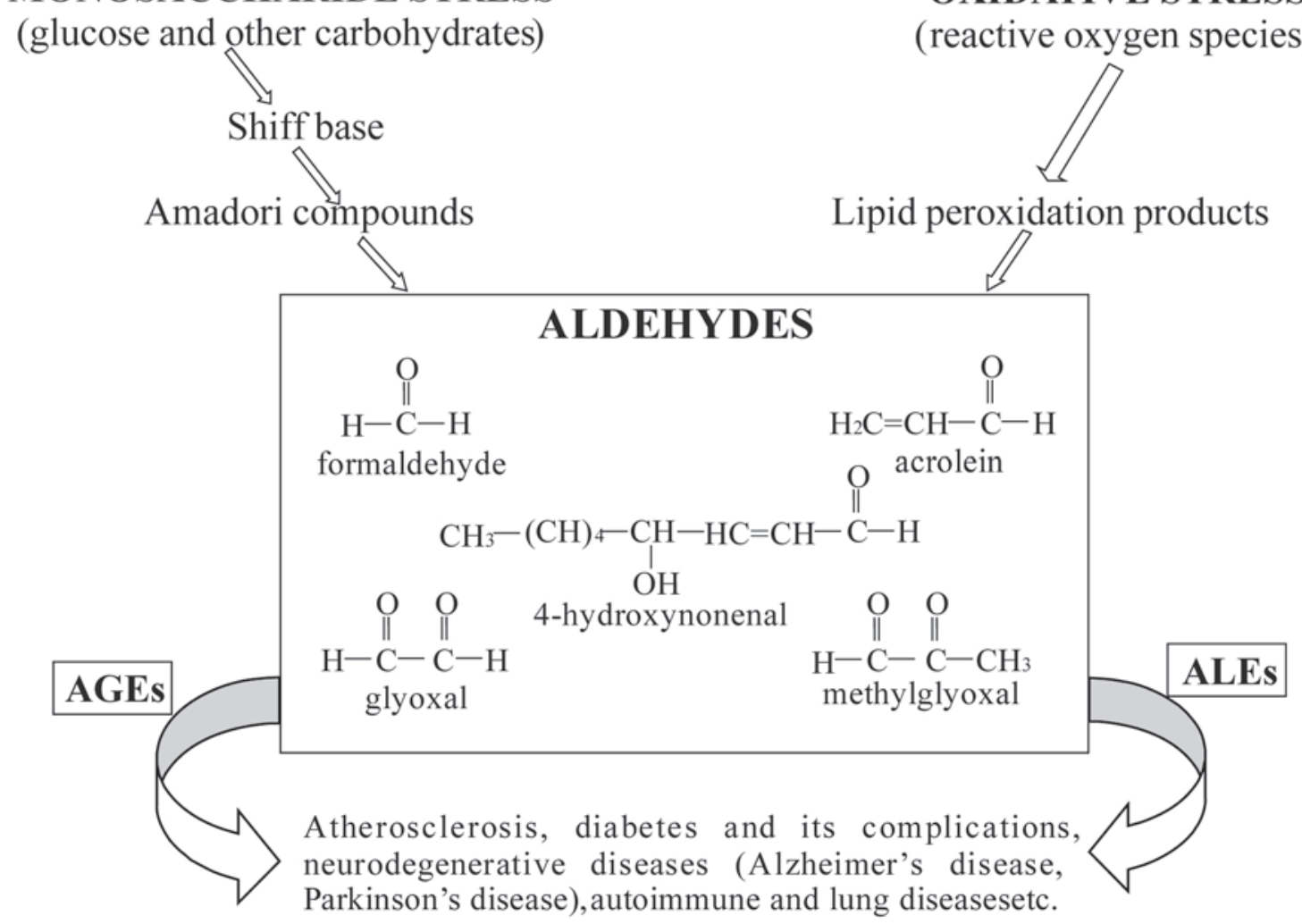

Fig. 1. Formation of aldehydes and advanced glycation and lipooxidation end products (AGEs and ALES) in oxidative and monosaccharide stresses

ACR is formed endogenously under POL and polyamines metabolism [10]. ACR may induce oxidative stress [11], react with proteins, phospholipids and DNA accompanied by formation of Michael adducts [12]. Mechanisms of the ACR action are not fully established, but recent researches demonstrate that this carbonyl compound is able to connect and cleavage cell nucleophiles, such as reduced glutathione, lipoic acid and thioredoxin [10]. It can attack free thiol groups of cysteine and $\gamma$-amino groups of lysine and histidine with ACR-amino acid adducts and carbonyl groups of proteins [13] formation. These conversions lead to disturbance of protein functions.

GL and MGL are well-researched glycation agents, which throughout modification of arginine residues form cross-links in proteins and cause their dysfunction [14]. The ability of MGL to induce oxidative stress [15] was demonstrated by Desai, Chang et al. on the different types of cells. These results indicate that aldehydes, are formed on the crossing of different metabolic ways, are very important for research of these processes.
Oxidative stress is one of the cell death inductors. An increase of ROS production by cell causes potential threat of oxidative damage to biomolecules. Suspension of isolated thymocytes (non-fully differentiated T-cells) is a useful model for research of oxidative stress development. Maturation of T-cells in thymus is a highly-organized process. Any deviation in it causes immune deficiency, autoimmune reactions or cancer. These cells, in comparison to other types of cells, are easily isolated, morphologically homogeneous and more sensitive to different damaging influences of chemical or physical factors. They are suitable for flow cytometry because of their spherical shape and size.

Oxidative stress is implicated in the pathogenesis of many chronic and degenerative diseases. Carbonyl compounds increase or carbonyl stress is a consequence of oxidative stress. Nowadays, the research of aldehydes role during oxidative stress and development of treatment aimed at carbonyl stress decrease under pathologies related to oxidative and carbon stresses, are important. 
The aim of this research is the investigation of oxidative stress parameters formation and aldehydes possibility to oxidative stress induction in rat's thymocytes. Two models were used: iron-induced oxidative stress and exogenous aldehydes such as FA, GL, MGL and ACR exposure to thymocytes.

\section{Materials and Methods}

Experiments were performed on thymocytes obtained from Wistar rats of 80-100 g weight which have been used for research. All manipulations with animals followed the Guide for the Care and Use of Laboratory Animals (1996) and followed Law of Ukraine on Protection of Animals from Cruel Treatment (published by Supreme Council of Ukraine, 2006, No 27, paper 230). Thymus glands were gently triturated in chilled Hanks' balanced salt solution (HBSS, Sigma, USA) supplemented with $10 \mathrm{mM}$ Tris- $\mathrm{HCl}(\mathrm{pH}$ 7.2) to dissociate single cells. This solution with cells was passed through a nylon mesh and suspended for two times in HBSS centrifuged at $1000 \mathrm{~g}$ for $5 \mathrm{~min}$. Cell counting was performed with $0.4 \%$ trypan blue (Sigma, USA) in Neubauer hemocytometer.

In the first part of the research, for oxidative stress induction freshly prepared $20,30,40 \mu \mathrm{M}$ $\mathrm{FeSO}_{4}$ solutions in Tris- $\mathrm{HCl}(\mathrm{pH} 7.2)$ and ascorbic acid $(100 \mu \mathrm{M})$ were added to thymocytes suspension $\left(2 \times 10^{6} \mathrm{cell} / \mathrm{ml}\right.$ HBSS, $\mathrm{pH}$ 7.2). Cells were incubated at $37{ }^{\circ} \mathrm{C}$ for 6 hours. To separate the role of aldehydes, the acceptor dimedone $(200 \mu \mathrm{M}$, Sigma, USA) prepared in distilled water was added.

In the second part of the research, freshly prepared different-concentrated aldehydes solutions: ACR (Sigma, USA) - 1, 5, 10, $15 \mu \mathrm{M}, \mathrm{FA}$ (Alfarus, Ukraine) - 50, 200, $600 \mu \mathrm{M}$, GL (Alfarus, Ukraine) - 50, 200, $600 \mu \mathrm{M}$, MGL (Sigma, USA) $50,200,600 \mu \mathrm{M}$ were added to the thymocytes suspension $\left(2 \times 10^{6}\right.$ cells $\left./ \mathrm{ml} \mathrm{HBSS}, \mathrm{pH} 7.2\right)$.

Cell viability was assessed by flow cytometry with ethidium bromide (Fisher BioReagents, Canada). Ethidium bromide was added to cell suspension to achieve a final concentration of $15 \mu \mathrm{M}$. Ethidium fluorescence was measured after 15 min incubation at room temperature by flow cytometer COULTER EPICS XL (Beckman Coulter, USA, $\lambda_{\text {ex. }}=488 \mathrm{~nm}$ ), determining intensity of fluorescence by FL-3 channel $(620-630 \mathrm{~nm})$. Ethidium fluorescence monitored from 10000 events for every sample was analyzed by FCS Express V3 Software. Samples were preserved for no more than $1 \mathrm{~h}$ at $4{ }^{\circ} \mathrm{C}$.
Cells were washed twice by cold phosphate buffer ( $\mathrm{pH}$ 7.4), suspended in RIPA buffer (contained $20 \mathrm{mM}$ Tris- $\mathrm{HCl}, 150 \mathrm{mM} \mathrm{NaCl}, 1 \mathrm{mM} \mathrm{NaF}, 0.5 \mathrm{mM}$ EDTA, $0.5 \mathrm{mM}$ EGTA, $10 \mathrm{mM}$ Na-pyrophosphate, $\mathrm{pH} 7.5 ; 600 \mu \mathrm{R}$ RPA $/ 10^{7}$ cells), carefully mixed with syringe using and lysed by incubation on ice bath for $30 \mathrm{~min}$. After centrifugation at $12000 \mathrm{~g}$ for $20 \mathrm{~min}$ cell lysates were obtained.

Aldehydes concentrations in cell lysates were determined by Purpald (Sigma, USA). The optical density was measured spectrophotometrically by $\mu$ Quant (Biotek, USA) at $550 \mathrm{~nm}$. Different-concentrated formaldehyde solutions were used for calibration [19].

Lipid peroxidation in cells was measured with the thiobarbituric acid assay (TBARS) [16]. The optical density was measured spectrophotometrically at $532 \mathrm{~nm}$ by $\mu$ Quant (Biotek, USA). The TBARS were quantified using 1,1,3,3-tetraethoxypropane as the standard.

Protein carbonyl groups were determined by modified spectrophotometric method [20].

Protein level was evaluated by Lowry assay (Peterson' modification) [18].

The levels of low-molecular weight SH-groups were determined in lysates with o-phthalaldehyde (Fluka, Austria) assay by M. L. Hu [17]. Excitation wavelength for o-phthalaldehyde was $360 \mathrm{~nm}$ and emission was detected at $420 \mathrm{~nm}$ by FL800 (Biotek, USA). Reduced glutation was used as standard (Sigma, USA).

Cell mitochondrial activity was determined by Alamar Blue (AB, Sigma, USA) reduction. AB is a redox indicator, which determine the live cell metabolic activity. The system includes redox nonfluorescent indicator (resazurin), which is converted in fluorescent form (rezorufin) as a result of chemical reduction by living cells [21]. AB final concentration in a sample was $5 \mu \mathrm{M}$. Cells were incubated at $37{ }^{\circ} \mathrm{C}$ for $2 \mathrm{~h}$. Fluorescence is monitored at $560 \mathrm{~nm}$ excitation wavelength and $600 \mathrm{~nm}$ emission wavelength by FL800 (Biotek, USA). Cell viability was expressed as a percentage of the $\mathrm{AB}$ reduction in control $(100 \%)$.

Statistical analyses has been done with using Student's test $(P<0.05)$ and MS Excel 2007.

\section{Results and Discussion}

In this paper, iron-induced oxidative stress in thymocytes was used to research the aldehydes involvement in development of oxidative stress. Tran- 
sition metals act as catalysts during oxidative damage of biological macromolecules. Number of metals such as iron, copper, cadmium, chrome, nickel and vanadium are able to create active forms of oxygen that lead to POL increase, DNA damage, sulfhydryl group depletion and calcium homeostasis disturbance. It is well documented that iron, the most abundant transition metal, can induce the generation of free radicals, which attack important biomolecules including proteins, deoxynucleic acids, and lipid membranes and thus cause oxidative stress. $\mathrm{H}_{2} \mathrm{O}_{2}$ with iron can produce reactive $\mathrm{HO}^{*}$ radicals or ferryl intermediate by the Fenton reaction.

It was demonstrated that exposure of cells to 20, 30 and $40 \mu \mathrm{M} \mathrm{FeSO}_{4}$ for $6 \mathrm{~h}$ resulted in significant dose-dependent decrease of cell viability: 1.7 times, 2.2 times and 3.5 times, respectively, compared with control. Obtained results were demonstrated in Table 1.

Total levels of aldehydes increase at $20 \mu \mathrm{M}$ 13.5 times, at $30 \mu \mathrm{M} 23$ times and at $40 \mu \mathrm{M} 29$ times compared with control were demonstrated. This changes of levels of aldehydes led to dosedependent lipid peroxidation in thymocytes that was indicated by increase in TBARS levels about 3-4 times. Levels of protein CO groups were increased 5 times, 8.3 times and 10 times, respectively, at 20, 30 and $40 \mu \mathrm{M} \mathrm{FeSO}_{4}$ compared with control. Lowmolecular weight $\mathrm{SH}$ groups and mitochondrial activity were decreased about 2 times and 1.5 times compared with control. Thus, the obtained results was proved oxidative stress development which was accompanied by formation of active carbonyl compounds such as aldehydes.

Dimedone was used to separate the aldehydes participation in formation of oxidative stress parameters in rat's thymocytes. Dimedone is used as acceptor of aldehydes through complex al-dimedone formation. In such way there occurred a decrease of aldehydes concentration. Fig. 2 demonstrates the mechanism of interaction between dimedone and aldehydes.

After dimedone addition a decrease of the total levels of aldehydes 3.7 times and 1.2 times at 20 and $30 \mu \mathrm{M} \mathrm{FeSO}_{4}$, respectively, were observed. At $40 \mu \mathrm{M} \mathrm{FeSO}_{4}$ aldehydes level was not changed due to high concentration of iron but there was a visible tendency to a decrease that proved the effective acceptance of it. A decrease of other parameters were observed. TBARS levels were decreased 1.6 times, 1.2 times and 1.3 times, protein $\mathrm{CO}$ groups levels 2 times, 5 times and 3 times compared with 20,30 and $40 \mu \mathrm{M} \mathrm{FeSO}_{4}$ without dimedone addition. SH groups levels were increased 1.5 and 1.8 times at $30 \mu \mathrm{M}$ and $40 \mu \mathrm{M} \mathrm{FeSO}_{4}$. Mitochondrial activity increase and improvement of cell viability after dimedone addition were observed.

Thus, the application of dimedone has allowed to separate the aldehydes participation in oxidative stress development under iron-induced oxidative stress in rat's thymocytes. Dimedone, due to its acceptor features, may be used for decreasing the oxidative stress development, where aldehydes play an important role.

Table 1. Biochemical parameters of oxidative stress development in thymocytes under iron-induced oxidative stress and dimedone addition, $(n=6)$

\begin{tabular}{l|c|c|c|c|c|c}
\hline $\begin{array}{c}\text { Iron } \\
\text { concentrations, } \\
\mu \mathrm{M}\end{array}$ & $\begin{array}{c}\text { Cell } \\
\text { viability, } \\
\% \text { of dead } \\
\text { cells }\end{array}$ & $\begin{array}{c}\text { TBARS, } \\
\text { nmol/10 } \\
\text { cells }\end{array}$ & $\begin{array}{c}\text { Protein CO } \\
\text { groups, } \\
\text { nmol/mg } \\
\text { protein }\end{array}$ & $\begin{array}{c}\text { SH groups, } \\
\text { nmol/10 } \\
\text { cells }\end{array}$ & $\begin{array}{c}\text { Mitochondrial } \\
\text { activity, } \\
\% \text { of Alamar } \\
\text { Blue reduction }\end{array}$ & $\begin{array}{c}\text { Aldehydes, } \\
\text { nmol/ } 10^{7} \\
\text { cells }\end{array}$ \\
\hline control & $8 \pm 1$ & $0.90 \pm 0.05$ & $0.12 \pm 0.01$ & $0.45 \pm 0.01$ & $100 \pm 5$ & $3.1 \pm 0,3$ \\
20 & $14 \pm 2$ & $2.5 \pm 0.3^{*}$ & $0.60 \pm 0.01^{*}$ & $0.24 \pm 0.01^{*}$ & $93 \pm 10$ & $42 \pm 5^{*}$ \\
30 & $18 \pm 5^{*}$ & $3.4 \pm 0.6^{*}$ & $1.00 \pm 0.03^{*}$ & $0.20 \pm 0.03^{*}$ & $85 \pm 8^{*}$ & $72 \pm 5^{*}$ \\
40 & $28 \pm 6^{*}$ & $4.0 \pm 0.9^{*}$ & $1.20 \pm 0.05^{*}$ & $0.19 \pm 0.02^{*}$ & $65 \pm 9^{*}$ & $90 \pm 6^{*}$ \\
$20+$ dimedone & $13 \pm 3$ & $1.5 \pm 0.4$ & $0.30 \pm 0.01^{* *}$ & $0.24 \pm 0.02$ & $98 \pm 11$ & $11.0 \pm 0.5^{* *}$ \\
$30+$ dimedone & $22 \pm 3$ & $2.5 \pm 0.6^{* *}$ & $0.20 \pm 0.01^{* *}$ & $0.30 \pm 0.01^{* *}$ & $95 \pm 13$ & $60 \pm 2^{* *}$ \\
$40+$ dimedone & $25 \pm 5^{* *}$ & $3.1 \pm 0.1^{* *}$ & $0.40 \pm 0.01^{* *}$ & $0.35 \pm 0.01^{* *}$ & $90 \pm 9^{* *}$ & $85 \pm 10$ \\
\hline
\end{tabular}

$* P<0.05$ compared with control, ${ }^{* *} P<0.05$ compared with cells exposure to $\mathrm{FeSO}_{4}$. 


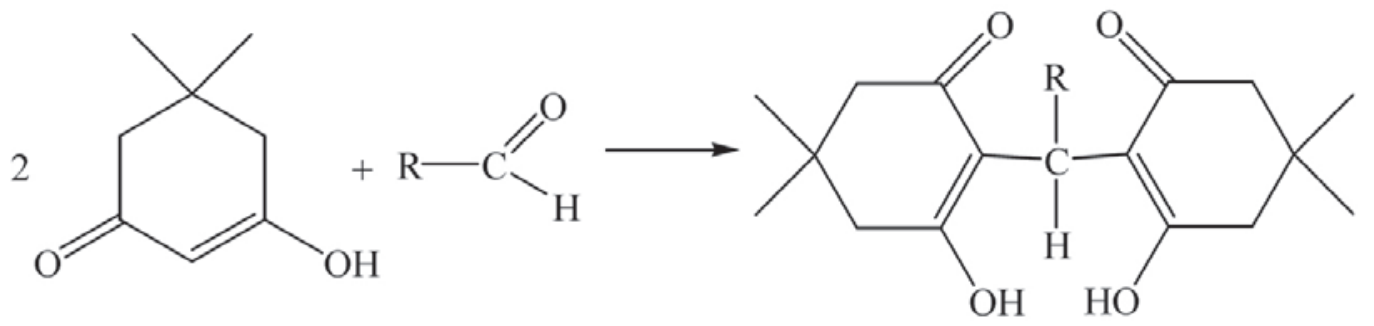

Fig. 2. The formation of complex between dimedone and aldehyde [29]

Ability of such exogenous aldehydes as FA, ACR, GL, MGL to cause oxidative stress development in thymocytes was investigated in the second part of the research. Concentrations of exogenous aldehydes have been selected according to literature data and personal research.

ACR is highly reactive air pollutant, a metabolic product of the anti-cancer drug and by-product of lipid peroxidation. It is known that ACR is estimated to reach concentrations up to $80 \mu \mathrm{M}$ in respiratory tract lining fluids as a result of smoking (Eiserich et al., 1995) [22]. In vivo ACR concentrations in Alzhheimer' disease brain are $2.5 \mathrm{nmol} / \mathrm{mg}$ in amygdale and $5.0 \mathrm{nmol} / \mathrm{mg}$ in parahippocampal gyrus (Lovell et al., 2001). In vitro ACR concentrations from 25 to $100 \mu \mathrm{M}$ are lethal to pulmonary artery endothelial cells (Kachel and Martin, 1994), bronchiolar epithelial cells [23] and both bronchial (Krokan et al., 1988) and cardiac fibroblasts (Torasson et al., 1989).

Exposure of various concentrations of ACR to thymocytes was resulted in a dose-dependent decrease in cell viability. After $6 \mathrm{~h}$ exposure with $15 \mu \mathrm{M}$ ACR, the cell death level increased 4.5 times compared with control.

These results demonstrated the strongest toxic effect of ACR compared to the other investigated aldehydes to thymocytes even in low concentration. Based on these results, 1, 5, 10, $15 \mu \mathrm{M}$ ACR were used in research.

Exact concentrations of endogenous FA are quite hard to determine, because it metabolises very fast and non-metabolized one connects with tissue proteins. Nakao, Umebaysh et al. defined that concentration of FA in blood is about $100 \mu \mathrm{M}$ [24]. 50, $200,600 \mu \mathrm{M}$ FA were used in the investigation. The obtained data demonstrated that FA has the lowest cytotoxic effect to thymocytes compared with other aldehydes, because the percentage of dead cells at maximal concentration of FA $(600 \mu \mathrm{M})$ decreased 4 times compared with control.
Recent estimates of the concentrations of MGL and GL in human blood plasma are in the range of 100-120 $\mathrm{nM}$ [25] and cellular concentrations of MGL 1-5 $\mu \mathrm{M}$ and GL 0,1-1 $\mu \mathrm{M}$ [26]. It is known that MGL ( $>10 \mathrm{mM}$ ) inhibits glycolytic enzymes (Leonici et al., 1989). DNA crosslinking was observed at $1.5 \mathrm{mM}$ MGL in Chinese hamster ovary cells [27]. The $\mathrm{IC}_{50}$ for MGL is $8.6 \mathrm{mM}$ (for $S$. cerevisiae strain BY4743), approximately 5-fold less than that for glyoxal ( $\mathrm{IC}_{50}$ of $45.5 \mathrm{mM}$ ) (Hoon et al., 2011). Thornalley proposed that the effects of GL and MGL on cultured cells and tissues using at concentration $>10$-fold higher than this are likely to be only of relevance for acute intoxication and cytotoxicity [28].

Thornalley in their experiments with $E$. coli have used 0.2-1 mM MGL concentrations [27]. MGL and GL in the amount of 50,200, $600 \mu \mathrm{M}$ were used in our research. It has been demonstrated that after exposure to $600 \mu \mathrm{M}$ MGL and GL the level of dead cells increased 4.4 and 4.8 times, respectively. These results indicated the similarity of their cytotoxic effect.

The ability of investigated aldehydes to induce oxidative stress development was determined by change of such oxidative stress parameters as TBARS, protein CO groups, low-molecular weight $\mathrm{SH}$ groups, cell mitochondrial activity by AB reduction.

As shown in Table 2, TBARS level for FA was increased only 1.3 times while for GL about 5-6 times, for MGL 13 times and for ACR 30 times compared with control. The level of protein $\mathrm{CO}$ groups in cell lysates was increased in the same way. The lowest level of protein $\mathrm{CO}$ groups (about 3-4 times increase) was observed after exposure to FA. Depending on concentration this parameter was increase for GL 9-13 times, for MGL 5-7 times, for ACR 22 times compared with control. Level of lowmolecular weight $\mathrm{SH}$ groups was decreased for FA 
Table 2. Biochemical parameters of oxidative stress development in thymocytes after $6 \mathrm{~h}$ aldehydes exposure, $(n=6)$

\begin{tabular}{|c|c|c|c|c|c|}
\hline $\begin{array}{c}\text { Aldehydes } \\
\text { concentrations, } \\
\mu \mathrm{M}\end{array}$ & $\begin{array}{l}\text { Cell viability, } \\
\% \text { of dead cells }\end{array}$ & $\begin{array}{c}\text { TBARS, } \\
\text { nmol/ } / 10^{7} \text { cells }\end{array}$ & $\begin{array}{l}\text { Protein } \mathrm{CO} \\
\text { groups, nmol/ } \\
\text { mg protein }\end{array}$ & $\begin{array}{l}\mathrm{SH} \text { groups, } \\
\mathrm{nmol} / 10^{7} \text { cells }\end{array}$ & $\begin{array}{l}\text { Mitochondrial } \\
\text { activity, \% of } \\
\text { Alamar Blue } \\
\text { reduction }\end{array}$ \\
\hline Control & $8 \pm 1$ & $0.90 \pm 0.01$ & $0.17 \pm 0.01$ & $0.45 \pm 0.04$ & $100 \pm 5$ \\
\hline \multicolumn{6}{|c|}{ Formaldehyde } \\
\hline 50 & $15 \pm 2$ & $1.00 \pm 0.05$ & $0.35 \pm 0.09^{*}$ & $0.37 \pm 0.02 *$ & $99 \pm 15$ \\
\hline 200 & $19 \pm 4^{*}$ & $1.17 \pm 0.01$ & $0.5 \pm 0.2^{*}$ & $0.30 \pm 0.01^{*}$ & $86 \pm 8$ \\
\hline 600 & $32 \pm 2 *$ & $1.19 \pm 0.02 *$ & $0.63 \pm 0.06^{*}$ & $0.29 \pm 0.01^{*}$ & $75 \pm 9^{*}$ \\
\hline \multicolumn{6}{|c|}{ Glyoxal } \\
\hline 50 & $24 \pm 3^{*}$ & $2.30 \pm 0.02 *$ & $1.6 \pm 0.9^{*}$ & $0.21 \pm 0.01^{*}$ & $72 \pm 11^{*}$ \\
\hline 200 & $27 \pm 1^{*}$ & $5.30 \pm 0.02 *$ & $2.0 \pm 0.5^{*}$ & $0.20 \pm 0.01^{*}$ & $68 \pm 15^{*}$ \\
\hline 600 & $35 \pm 4^{*}$ & $4.30 \pm 0.01^{*}$ & $2.26 \pm 0.05^{*}$ & $0.15 \pm 0.01^{*}$ & $63 \pm 7^{*}$ \\
\hline \multicolumn{6}{|c|}{ Methylglyoxal } \\
\hline 50 & $20 \pm 6^{*}$ & $4.30 \pm 0.01^{*}$ & $0.8 \pm 0.3^{*}$ & $0.28 \pm 0.05^{*}$ & $85 \pm 13^{*}$ \\
\hline 200 & $26 \pm 1^{*}$ & $6.30 \pm 0.04^{*}$ & $0.9 \pm 0.4^{*}$ & $0.26 \pm 0.01^{*}$ & $83 \pm 18^{*}$ \\
\hline 600 & $38 \pm 6^{*}$ & $4.10 \pm 0.06^{*}$ & $1.2 \pm 0.2^{*}$ & $0.17 \pm 0.01^{*}$ & $77 \pm 10^{*}$ \\
\hline \multicolumn{6}{|c|}{ Acrolein } \\
\hline 1 & $10 \pm 3$ & $2.50 \pm 0.01^{*}$ & $0.47 \pm 0.01^{*}$ & $0.13 \pm 0.03^{*}$ & $96 \pm 4$ \\
\hline 5 & $15 \pm 5$ & $3.7 \pm 0.2^{*}$ & $0.74 \pm 0.01^{*}$ & $0.12 \pm 0.02 *$ & $69 \pm 6^{*}$ \\
\hline 10 & $24 \pm 8^{*}$ & $7.1 \pm 0.1^{*}$ & $1.0 \pm 0.3^{*}$ & $0.11 \pm 0.02^{*}$ & $68 \pm 13^{*}$ \\
\hline 15 & $36 \pm 6^{*}$ & $1.6 \pm 0.1^{*}$ & $3.70 \pm 0.01^{*}$ & $0.05 \pm 0.01^{*}$ & $56 \pm 9^{*}$ \\
\hline
\end{tabular}

$* P<0.05$ compared with control

about 1.5 times, for MGL up to 2 times, for ACR up to 9 times compared with control. Depending on concentration of aldehydes, a decrease of mitochondrial activity was observed for FA up to 1.3 times, for GL 1.3 times and for MGL 1.2 times, for ACR 1.7 times compared with control, which was accepted as $100 \%$.

The obtained results demonstrated that ACR is the most toxic aldehyde from investigated ones to thymocytes because it is a by-product of lipid peroxidation. FA demonstrates the least toxic effect, because it does not belong to aldehydes which generated under oxidation processes development.

In summary, the results of the current study demonstrated that aldehydes play the significant role in formation of oxidative stress parameters under iron-induced oxidative stress in rat's thymocytes. Elimination of aldehydes effect with dimedone using has allowed to demonstrate change in the oxidative stress parameters and to prove participation of aldehydes in their development. Besides, it was characterized the ability of such exogenous aldehydes as ACR, GL, MGL and FA to induce oxidative stress in thymocytes. A number of parameters were indicated for research the oxidative stress development. They are TBARS, CO groups of proteins, low-molecular weight SH groups and mitochondrial activity of cells. All investigated aldehydes to a greater or lesser degree take part in formation of these parameters.

The obtained data proved the possibility of aldehydes acceptors using for a decrease of carbonyl compounds negative effects under oxidative stress development. It provides a basis for designed medicines that may be acceptors of aldehydes. Such medicines may be successfully used as components of complex treatment programs for pathologies accompanied with oxidative stress. 


\section{УЧАСТЬ АЛЬДЕГІДІВ \\ В ОКСИДАТИВНОМУ СТРЕСІ \\ В ТИМОЦИТАХ ЩУРА IN VITRO}

\section{К. О. Токарчук, О. В. Зайцева}

\author{
Інститут біохімії ім. О. В. Палладіна \\ НАН України, Київ; \\ e-mail: kate_tokarchuk@ukr.net
}

За розвитку оксидативного стресу утворюються ліпідні радикали, подальша трансформація яких призводить до формування численних альдегідів, що є одним із чинників посилення постсинтетичних модифікацій протеїнів та ДНК. Мета роботи: дослідити роль альдегідів у формуванні показників оксидативного стресу в тимоцитах щура in vitro. Для цього було використано дві моделі: залізоіндукований оксидативний стрес та інкубація екзогенних альдегідів із тимоцитами.

За використання першої моделі для індукції оксидативного стресу суспензію тимоцитів $\left(2 \times 10^{6}\right.$ клітин/мл HBSS, pH 7,2) інкубували 6 годин 3 розчином $\mathrm{FeSO}_{4}(20,30,40$ мкМ) та аскорбіновою кислотою (100 мкМ). Показано підвищення загального вмісту альдегідів в 29 разів $\left(90 \pm 6\right.$ нмоль $/ 10^{7}$ клітин; контроль $3,1 \pm 0,3$ нмоль $/ 10^{7}$ клітин), при цьому рівень ТБКактивних продуктів підвищується в 4,4 раза, а рівень СО-груп протеїнів - в 10 разів. Рівень мітохондріальної активності клітин зменшується в 1,5 раза, а рівень низькомолекулярних $\mathrm{SH}-г р у п$ в 2,3 раза. Застосування розчину акцептору альдегідів димедону (200 мкМ) зменшує рівень альдегідів в 3,7 раза, ТБК-активних продуктів в 1,6 раза, СО-груп протеїнів в 5 разів, при цьому мітохондріальна активність підвищується в 1,4 раза, а рівень SН-груп в 1,8 раза.

У разі застосування другої моделі суспензію тимоцитів $\left(2 \times 10^{6}\right.$ клітин/мл HBSS, $\mathrm{pH}$ 7,2) інкубували 6 год 3 екзогенними альдегідами: формальдегідом (ФА), гліоксалем (ГЛ) та метилгліоксалем (МГЛ) - у діапазоні концентрацій від 50 до 600 мкМ, акролеїном (АКР) - 1-15 мкМ. Рівень ТБК-активних продуктів збільшується для ФА в 1,3 раза, для інших альдегідів в 5-7 разів. Рівень СО-груп протеїнів підвищується для ФА в 3,7 раза, для МГЛ в 7 разів, для ГЛ в 13 разів, для АКР в 22 рази. Рівень SН-груп знижується для ФА в 1,5 раза, для МГЛ в 2,6 раза, для ГЛ в 3 рази, для АКР в 9 разів. Спостерігається зниження мітохондріальної активності клітин приблизно в 1,5 раза для всіх альдегідів. Одержані результати доводять безпосередню участь альдегідів у формуванні показників оксидативного стресу в тимоцитах щура.

К л ю ч о в і сл о в а : оксидативний стрес, альдегіди, димедон, тимоцити.

\section{УЧАСТИЕ АЛЬДЕГИДОВ \\ В ОКСИДАТИВНОМ СТРЕССЕ В ТИМОЦИТАХ КРЫСЫ IN VITRO}

\section{К. А. Токарчук, О. В. Зайчуева}

Институт биохимии им. О. В. Палладина НАН Украины, Киев; e-mail: kate_tokarchuk@ukr.net

При развитии оксидативного стресса образуются липидные радикалы, трансформация которых приводит к формированию множества альдегидов, что и есть одним из факторов усиления постсинтетических модификаций протеинов и ДНК. Цель работы: исследовать роль альдегидов в формировании показателей оксидативного стресса в тимоцитах крысы in vitro. Для этого было использовано две модели: железоиндуцированный оксидативный стресс и инкубация экзогенных альдегидов с тимоцитами крысы.

Используя первую модель для индукции оксидативного стресса, суспензию тимоцитов $\left(2 \times 10^{6}\right.$ клеток/мл HBSS, pH 7,2) инкубировали 6 часов с раствором $\mathrm{FeSO}_{4}(20,30,40$ мкM) и аскорбиновой кислотой (100 мкМ). Показано увеличение общего содержания альдегидов в 29 раз $\left(90 \pm 6\right.$ нмоль $/ 10^{7}$ клеток; контроль $3,1 \pm 0,3$ нмоль $/ 10^{7}$ клеток), при этом уровень ТБК-активных продуктов увеличивается в 4,4 раза, а уровень СО-групп протеинов - в 10 раз. Уровень митохондриальной активности клеток уменьшается в 1,5 раза, а уровень низкомоле-

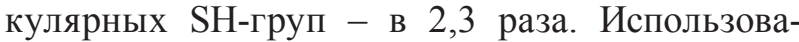
ние раствора акцептора альдегидов димедона (200 мкМ) снижает уровень альдегидов в 3,7 раза, ТБК-активных продуктов в 1,6 раза, СОгрупп протеинов в 5 раз, при этом митохондриальная активность увеличивается в 1,4 раза, а уровень $\mathrm{SH}-г$ руп в 1,8 раза.

При применении другой модели суспензию тимоцитов $\left(2 \times 10^{6} /\right.$ мл HBSS, pH 7,2) инкубирова- 
ли 6 часов с экзогенными альдегидами: формальдегидом (ФА), глиоксалем (ГЛ) и метилглиоксалем (МГЛ) - в диапазоне концентраций от 50 до 600 мкМ, акролеином (АКР) - 1-15 мкМ. Показано, что уровень ТБК-активных продуктов увеличивается для ФА в 1,3 раза, для остальных альдегидов - в 5-7 раз. Уровень СО-групп протеинов увеличивается для ФА в 3,7 раза, для МГЛ в 7 раз, для ГЛ в 13 раз, для АКР в 22 раза. Уровень SН-групп снижается для ФА в 1,5 раза, для МГЛ в 2,6 раза, для ГЛ в 3 раза, для АКР в 9 раз. Наблюдается снижение митохондриальной активности клеток приблизительно в 1,5 раза для всех альдегидов. Полученные результаты подтверждают непосредственное участие альдегидов в формировании показателей оксидативного стресса в тимоцитах крысы.

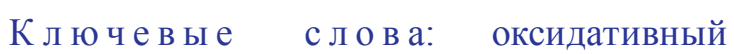
стресс, альдегиды, димедон, тимоциты.

1. Fanelli S. L., Maciel M. E., Díaz Gómez M. I., et al. // J. Appl. Toxicol. - 2011. - 31, N 1. - P. 1119.

2. Zhu Q., Sun Z., Jiang Y. et al. // Mol. Nutr. Food Res. - 2011. - 55, N 9. - P. 1375-1390.

3. Lui W., Kato M., Akhand A. et al. // J. Cell Sci. 2000. - 11, N 3. - P. 635-641.

4. Desai K. M., Chang T., Wang H. et al. // Can. J. Physiol. Pharmacol. - 2010. - 88. - P. 273-284.

5. Andersen M. E., Clewell H. J., Bermudez E. et al. // Toxicol. Sci. - 2010. - 118, N 2. - P. 716-731.

6. Zhu Q., Sun Z., Jiang Y. et al. // Mol. Nutr. Food Res. - 2011. - 55, N 9. - P. 1375-1390.

7. Radoi V., Lixandru D., Mohora M. et al. // Proc. Rom. Acad., Series B. - 2012. - 1. - P. 9-19.

8. Hipkiss A. R. // Exp. Gerontol. - 2006. - 41. P. 464-473.

9. Liesivuori J., Savolainen H. // Pharmacol. Toxicol. - 1991. - 69, N 3. - P. 157-163.

10. Mello C. F., Sultana R, Piroddi M. // Neuroscience. - 2007. - 147. - P. 674-679.
11. Park Y. S., Misonou Y., Fujiwara N. // Biochem. Biophys. Res. Commun. - 2005. - 327. P. 1058-1065.

12. Pocernich C. B., Butterfield D. A. // Neurotox. Res. - 2003. - 5. - P. 515-520.

13. Pocernich C. B., Cardin A. L., Racine C. L. et al. // Neurochem. Int. - 2001. - 39. - P. 141-149.

14. Rabbani N., Thornalley P. J. // Ann. N. Y. Acad. Sci. - 2008. - 1126. - P. 124-127.

15. Desai K. M., Chang T., Wang H. et al. // Can. J. Physiol. Pharmacol. - 2010. - 88. - P. 273-284.

16. Janero D. R. // Free Rad. Biol. Med. - 1990. - 9, N 6. - P. 515-540.

17. Hи M. L. // Methods Enzymol. - 1994. - 233. P. 380-385.

18. Peterson G. L. // Anal. Biochem. - 1977. - 83. P. 346-356.

19. Lee C. H., Tsai C. M. // Anal. Biochem. - 1999. 267. - P. 161-168.

20. Зайщева О. В., Шандренко С. Г. // Укр. біохім. журн. - 2012. - 84, № 5. - C. 112-116.

21. Rampersad S. N. // Sensors. - 2012. - 12, N 9. P. $12347-12360$.

22. Eiserich J. P., van der Vliet A, Handelman G. J. // Am. J. Clin. Nutr. - 1995. - 62. - P. 1490S-1500S.

23. Grafstrom R. C., Dypbukt J. M., Willey J. C. et al. // Cancer Res. - 1988. - 48. - P. 1717-1721.

24. Nakao H., Umebayshi C., Nakata M. et al. // J. Pharmacol. Sci. - 2003. - 91. - P. 83-86.

25. Beisswenger P. J., Howell S., Touchette A. et al. // Diabetes. - 1999. - 48. - P. 198-202.

26. Dobler D., Ahmed N., Song L. J. et al. // Diabetes. - 2006. - 55. - P. 1961-1969.

27. Thornalley P. J. // Biochem. J. - 1990. - 269. P. 1-11.

28. Thornalley P. J. // Drug Metabol Drug Interact. 2008. - 23, N 1-2. - P. 125-150.

29. Spencer D., Henshall T. // J. Am. Chem. Soc. 1955. - 77, N 7. - P. 1943-1948.

Received 02.10.2013 